\title{
Uptake of Barium from Vermiculite by the Bacterium Pseudomonas fluorescens - New Indications for Barium as a Palaeoproxy
}

\author{
Barbara Müller*
}

\author{
Clay Mineralogy Group, Institute for Geotechnical Engineering, ETH Zürich, 8093 Zürich, Switzerland and Geological \\ Institute, Swiss Federal Institute of Technology, 8092 Zürich, Switzerland
}

\begin{abstract}
The apparent association of biogenic barite $\left(\mathrm{BaSO}_{4}\right)$ and organic matter in marine sediments has given support to the idea of using Ba as a proxy for palaeoproductivity. Despite this general acceptance only a few unicellular organisms (acantharian, diatoms) are known to incorporate barium. In this work, we show that the bacterium Pseudomonas fluorescens is able to take up barium. Because natural seawater harbors numerous bacteria many of which may take up $\mathrm{Ba}$, this uptake of $\mathrm{Ba}$ explains why it may be considered a palaeoproxy. The introduction of this article reviews briefly what is known to date of $\mathrm{Ba}$ as a palaeoproxy, and what is known about bacterial interaction with Ba. Like other trace elements such as $\mathrm{Fe}, \mathrm{Mn}$ and $\mathrm{Sr}$, Ba can be extracted from vermiculite by Pseudomonas fluorescens and some mutants derived from it. Barium, therefore, seems to be as important a factor in bacterial metabolism as iron or other trace elements. The incorporation of Ba by living bacterial cells in the marine environment and its release from these cells upon their death and subsequent decay can contribute to $\mathrm{Ba}$ accumulation in marine sediments.
\end{abstract}

Keywords: Barium, bacterial metabolism, marine sediments, palaeoproductivity.

\section{INTRODUCTION}

The first description of the use of barium as a proxy for biological palaeoproductivity based on its association with the decomposition of organic matter and its enrichments in marine sediments was published by Goldberg and Arrhenius [1]. Since then this particular concept has been used by numerous authors (e.g. [2-14])

Several authors $[4,15,16]$ point to a fundamental aspect of the use of barium as a geochemical proxy: Ba seems to be an ideal proxy because barite (the main carrier of barium) is not as labile as organic matter or carbonate. The biogeochemical cycle of carbon has a major influence on the Earth's climate system. Variations in atmospheric $\mathrm{CO}_{2}$ are assumed to result from changes in ocean productivity by the burial of carbon derived from the atmosphere into the sediment, continental weathering, $\mathrm{CO}_{2}$ degassing from volcanoes, $\mathrm{CO}_{2}$ production at mid-ocenan ridges and LIPS (Large Igneous Provinces). Therefore, to estimate present and past primary production concerning sediments, sediment proxies other than organic matter or carbonate are needed. These sediment proxies have to reflect a strong correlation between productivity and their distribution in the sedimentary record.

The suitability of barium as a proxy of oceanic palaeoproductivity is nowadays widely accepted, at least for oceanic areas outside the direct influence of terrigenous and hydrothermal inputs (e.g. [4, 9, 17-20]).

*Address correspondence to this author at the EAWAG, Swiss Federal Institute of Aquatic Science and Technology, 8600 Dübendorf, Switzerland; Tel: +41 7965670 54; E-mail: barbara.mueller@erdw.ethz.ch
Barium distribution in seawater is characterized by surface water depletion and deep water enrichment (e.g. [21, 22]) or lowered concentrations in surface waters without reaching depletion $[19,23,24]$. Barium exhibits a nutrientlike profile which is indicative of $\mathrm{Ba}$ transport in biological debris (e.g. $[3,25,26])$. The association of Ba with biogenic particles is supported by the fact that sediments underlying highly productive surface waters are considerably enriched in $\mathrm{Ba}$ (see [1, 2, 4, 7, 8, 27-29]). In Dehairs et al. [8] it is stated that barite micro-crystals are an ubiquitous component of oceanic suspended matter and its biologic production in surface waters and their subsequent dissolution with depth plays a major role in the oceanic Ba cycle (see also [19, 24]). In Chow and Goldberg [27] it is considered that the formation of barite could take place in supersaturated microenvironments composed of biogenic detritus [6-8, 19, $24,28,30]$.

Several observations indicate that biochemical processes are involved in the formation of $\mathrm{BaSO}_{4}$ in the water column. It has been suggested by Dehairs et al. [8] that uptake of $\mathrm{Ba}$ by organisms and their debris is a vital mechanism for the accumulation of barium. In Turekian [31] the particular distribution of $\mathrm{Ba}$ in sediments is described and explained by the production of barium sulphate crystals in association with biological activity. Moreover, the $\mathrm{Ba}$ content of suspended matter is positively correlated with plankton activity [32].

The involvement of barite in some biological processes has been confirmed by the observation of barite crystals within the protoplasm of abyssal benthic Rhizopoda of the class Xenophyophorida [33, 34]. Active intracellular production of barite is known to occur for some marine and freshwater algal and protozoan species [35-38] as well as in 
bacteria [39]. It has also been shown that barite crystal formation occurs in association with phytoplankton activity $[28,40,41]$.

Various other organisms were proposed to incorporate $\mathrm{Ba}$ in their life processes. In Bernstein et al. [25, 42, 43] the incorporation and subsequent release after decay of $\mathrm{Ba}$ from marine protozoans of the genus Acantharia, which secrete skeletal and cystic structural structures composed of celestite $\left(\mathrm{SrSO}_{4}\right)$ is documented. Other authors have also reported the presence of traces of barium in acantharian celestite [44-46]. Because of the good correlation between dissolved barium and silicon within the water column, the distribution of both elements is often proposed to be governed by the dissolution of Ba-enriched siliceous frustules, e.g. from diatoms [7, 4753]. In Ganeshram et al. [54] and Sternberg et al. [55] details about the experimental uptake of barium by phytoplankton and diatoms are presented, respectively. In Dehairs et al. [14] the bacterial influence of barium accumulation in marine sediments is first described.

Müller [56] represents one of the few articles ever published about the uptake of trace metals by a bacterium (Pseudomonas fluorescens strain CHA0 and mutants derived from it) from geological material like clay. The attention was turned to the removal of trace metals from clay minerals because clay minerals are omnipresent in natural soil, subsoil and rocks including marine sediments. Bacteria are also able to sequester trace elements in their cell wall and to release them again (e.g. $[57,58])$. Macronutrients like $\mathrm{K}, \mathrm{Na}, \mathrm{Ca}$, $\mathrm{Mg}, \mathrm{Al}$ and $\mathrm{NH}_{4}$ as well as trace element micronutrients like $\mathrm{V}, \mathrm{Mn}, \mathrm{Fe}, \mathrm{Co}, \mathrm{Ni}, \mathrm{Cu}$ or $\mathrm{Zn}$ are widely found in bacterial metabolites. Because of their low concentrations in most environments, metals and trace elements require organic ligands for their transport. Besides $\mathrm{Fe}$, trace elements like $\mathrm{Cu}, \mathrm{Zn}$ and $\mathrm{Mn}$ seem to play a major role in biocontrol activity of bacteria (e.g. [59, 60]). Experimental results indicate a net uptake of barium by all the bacterial strains used for these investigations. Barium, therefore, appears to play an important role in bacterial metabolism as does iron and other trace elements. In contrast to barite $\left(\mathrm{BaSO}_{4}\right.$, the main mineral carrier of $\mathrm{Ba}$ ), all carbon bearing products of metabolism are nonpermanent. Consequently bacteria exhibit a major source of barium available for sedimentary accumulation. The objective of this study was to show definitively that the incorporation of barium during bacterial metabolism and its release upon decay of the procaryotes leading to accumulation of barium in sediments.

\section{MATERIALS AND METHODS}

\section{Sample Preparation}

Vermiculite supplied by Thermex, Austria, was used for all the experiments. Prior to use, the vermiculite was expanded by heating with concentrated $\mathrm{H}_{2} \mathrm{O}_{2}(30 \%)$, in order to remove all organic material, and crushed with a mixer and either oven $\left(60^{\circ} \mathrm{C}\right)$ or air dried. The dry vermiculite was ground in a mortar down to a particle size range from 1 to 80 $\mu \mathrm{m}$.

A 30 g-quantity of vermiculate was dispersed in $1 \mathrm{~L}$ of growth medium containing $25 \mathrm{mM} \mathrm{NaH} \mathrm{PO}_{4}, 25 \mathrm{mM}$ $\mathrm{Na}_{2} \mathrm{HPO}_{4}$ (buffer to maintain the $\mathrm{pH}$ throughout the experiments at about 6.8), $7.6 \mathrm{mM}\left(\mathrm{NH}_{4}\right)_{2} \mathrm{SO}_{4}, 1.7 \mathrm{mM}$ $\mathrm{NaCl}, 10 \mathrm{mM}$ glucose and $10 \mathrm{mM}$ mannitol. The growth of Pseudomonas fluorescens during the experiments was monitored by measuring the optical density of the slurries with and without bacteria by UV spectroscopy.

After a two week incubation period the vermiculite was freed from the bacteria by ultrasonic sound treatment of five minutes. The supernatant was removed after centrifugation and the vermiculite air dried. Fused glasses of the vermiculite samples were prepared by mixing a 5:1 ratio of flux $\left(\mathrm{Li}_{2} \mathrm{~B}_{4} \mathrm{O}_{7}\right)$ and the finely ground samples for the analysis of trace elements by Laser Ablation ICP-MS.

\section{XRF and LA-ICP-MS}

$\mathrm{XRF}$ analysis of the fused glasses in order to determine major elements to be used as internal standards for LA ICPMS were carried out routinely at the Institute for Mineralogy and Petrography at ETH Zürich using a wave-length dispersive X-ray fluorescence spectrometer (WD-XRF, Axios, PANalytical).

The LA ICP-MS analyses of major, minor and trace elements were performed using a pulsed $193 \mathrm{~nm}$ ArF Excimer laser (Lambda Physik, Germany) with a homogeneous beam delivery prototype system similar to a Geolas (Microlas, Germany) in combination with an ELAN 6100 DRC (Perkin Elmer, Canada) ICP-MS [61].

Data analysis was undertaken using the software LAMTRACE and in-house spreadsheets following methods previously described $[62,63]$.

Limits of detection were calculated for each element and established at three times the standard deviation of the background signal (measured before laser ablation) divided by element sensitivity during the respective ablation.

A complete description of the procedures established for the batch experiments and the analytical procedure has been published [56, 64, 65].

\section{RESULTS}

Originally we examined our vermiculite samples for the presence of 30 trace elements ( $\mathrm{Sc}, \mathrm{Ti}, \mathrm{V}, \mathrm{Cr}, \mathrm{Mn}, \mathrm{Fe}, \mathrm{Co}, \mathrm{Ni}$, $\mathrm{Cu}, \mathrm{Zn}, \mathrm{As}, \mathrm{Rb}, \mathrm{Sr}, \mathrm{Y}, \mathrm{Zr}, \mathrm{Nb}, \mathrm{Mo}, \mathrm{Ag}, \mathrm{Cd}, \mathrm{Sn}, \mathrm{Sb}, \mathrm{Cs}, \mathrm{Ba}$, $\mathrm{La}, \mathrm{Ce}, \mathrm{W}, \mathrm{Tl}, \mathrm{Pb}, \mathrm{Bi}, \mathrm{U})$. All trace elements with the exception of barium were presented and discussed in Müller [66]. The results of the analyses of barium are published separately because of the significance of this element as a palaeoproxy.

As soon as the concentration of a particular element in vermiculite mixed with bacteria is statistically significantly lower than in the original vermiculite and the abiotic control, the interpretation is that the element has been taken up by the microbes. The supernatant solution was scanned by AAS (Perkin Elmer 1100) for a variety of trace elements but no significant content concerning the trace elements of interest were detected. For a complete description of the analytical procedures established for the batch experiments and the analytical procedure see $[56,64,65]$. 
All the secondary metabolites produced by the wild type CHA0 and the various mutants show the ability to complex a variety of these trace elements (see tables 1 and 2 in Müller [56]). Whereas macronutrients like $\mathrm{C}, \mathrm{O}, \mathrm{N}, \mathrm{H}, \mathrm{P} . \mathrm{Ca}, \mathrm{Mg}$, $\mathrm{K}, \mathrm{S}, \mathrm{Na}$ and $\mathrm{Cl}$ constitute the bulk of the bacterial cells (e.g. $[67,68])$, many trace elements and metals are found specifically in proteins: Among those are $\mathrm{V}, \mathrm{Mn}, \mathrm{Fe}, \mathrm{Co}, \mathrm{Ni}$, $\mathrm{Cu}, \mathrm{Zn}$ and $\mathrm{Ba}$ [69]. Table 1 exhibits the results of the LA ICP-MS analysis of barium. Fig. (1) illustrates these results of the statistical analyses. All the bacterial strains incorporated barium in trace amounts. The distribution pattern of the barium uptake by the microbes is very similar to those for $\mathrm{Fe}, \mathrm{Mn}, \mathrm{Sr}, \mathrm{Y}, \mathrm{La}$ and $\mathrm{Ce}$ (for details see Müller [56]).

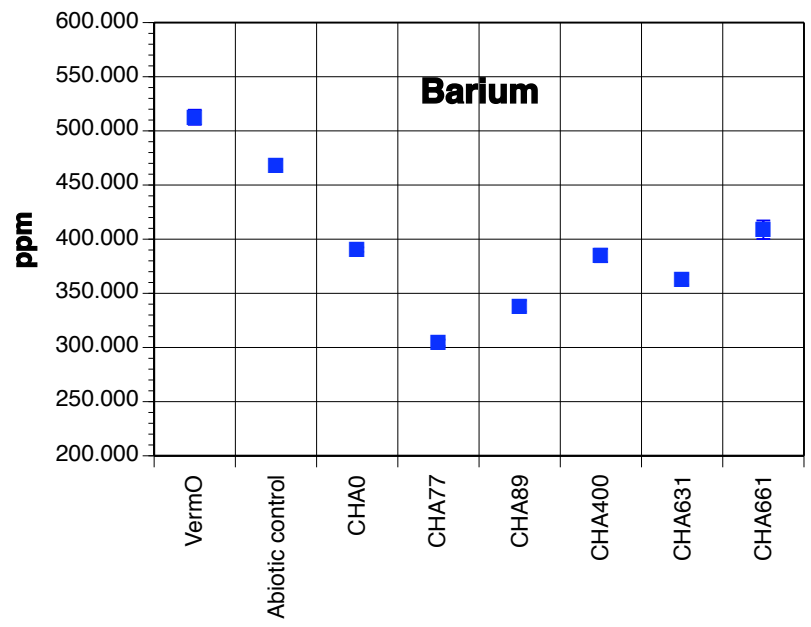

Fig. (1). Barium concentrations with their respective error bars (proportional to the standard deviation which is commonly smaller than the symbol) for all of the samples analyzed.

\section{DISCUSSION AND CONCLUSION}

In the introduction of this article a brief review of what is known to date of $\mathrm{Ba}$ as a palaeoproxy, and what is known about bacterial interaction with Ba was given. Therefore, the disscussion will be focused on the incorporation of $\mathrm{Ba}$ as a trace element on bacterial metabolism and to illustrate this way the new insights of Ba to be used as a paleoproxy.

Müller [56] described the uptake of various trace elements (Mn, Fe, Co, Cu, Zn, Sr, Y, Zr, La, Ce, U) by Pseudomonas fluorescens strain CHA0 and its genetic derivatives. The uptake of barium, as outlined above, completes this picture. Different alternatives concerning incorporation of trace elements by bacteria include: (1) uptake of trace elements into the cells or cell walls; (2) incorporation in coatings on the clay mineral; (3) storage of elements in biofilm and (4) incorporation of trace elements in proteins, enzymes and other products of bacterial metabolism. All these mechanisms concerning barium deserve consideration as the inclusion of barium in bacterial metabolism and the further release of Ba upon decay of the procaryotes presents a basic process for its accumulation in sediments and the use of $\mathrm{Ba}$ as a palaeoproxy.

In Vahrenkamp [70] a comprehensive overview concerning metals in life processes is provided. Like other metals, barium can either be toxic (as soluble compound) or harmless (in the form of the hardly soluble mineral barite $\left.\left(\mathrm{BaSO}_{4}\right)\right)$.

Unfortunately, little is known about the role of barium in bacterial cells because $\mathrm{Ba}$ is not as frequently used as a trace element for life processes by bacteria as are $\mathrm{Na}, \mathrm{K}, \mathrm{Ca}, \mathrm{Mg}$, and $\mathrm{Fe}$ but it nevertheless an important share concerning bacterial metabolism. To illustrate this fact, it is pointed out that almost all of the most abundant elements within the earth's crust exhibit a lower atomic number (30) than zinc which, in turn, is the last element of the first transition row of the periodic table of the elements. Only $\mathrm{Rb}, \mathrm{Sr}, \mathrm{Zr}$ and $\mathrm{Ba}$ are more commonly than $\mathrm{Zn}$ within the earth's crust. The most abundant elements within the earth's crust play a major role concerning the metabolism of all sorts of life forms [70].

In Goytain and Quamme [69], ACDP2 (ancient conserved domain protein) is reported to be a divalent metal transporter including $\mathrm{Mg}^{2+}, \mathrm{Mn}^{2+}, \mathrm{Fe}^{2+}, \mathrm{Co}^{2+}, \mathrm{Cu}^{2+}, \mathrm{Sr}^{2+}$ and $\mathrm{Ba}^{2+}$. The ACDP family proteins are conserved in some form from bacteria to man and women (see also [71]). In Goytain and Quamme [69] the authors concluded also that the cellular accumulation and intracellular distribution of the above mentioned divalent cations may be changed with magnesium deficiency. The interaction between several heavy elements ( $\mathrm{Al}, \mathrm{Ba}, \mathrm{Cd}, \mathrm{Co}, \mathrm{Cr}, \mathrm{Cs}, \mathrm{Cu}, \mathrm{Fe}, \mathrm{Ga}, \mathrm{Mn}, \mathrm{Ni}$, $\mathrm{Rb}, \mathrm{Pb}, \mathrm{Si}, \mathrm{Sn}, \mathrm{Sr}, \mathrm{Ti}, \mathrm{U}$, and $\mathrm{Zn}$ ) and three different Bacillus isolates were studied in [72]. The ability to interact with the elements mentioned was investigated in vegetative cells and spores of Bacillus strains as well as those of the corresponding reference strains $B$. cereus ATCC 4415, B. megaterium NRRL B5385, and B. sphaericus NCTC 9602. Cells and spores were capable of taking up Ba. $B$. sphaericus/JG-A12 and B. cereus/JG-A30 shared almost the same binding capability to each particular metal ion involved in the experiments including $\mathrm{Ba}$.

In Dong et al. [73], the authors published an article about the adsorption of lead, cadmium, copper, zinc and barium on freshwater surface coatings. $\mathrm{Ba}$ is reported to be the least adsorbed element among those used in the study. In Xiong et al. [74], six deep-sea proteolytic (decomposing) bacteria taken from Aleutian margin sediments (a deep-sea environment), which produced different proteases (enzymes

Table 1. Concentration (in ppm) and confidence interval for barium as determined by LA ICP-MS in vermiculite. The original vermiculite is denoted VermO. Vermiculite from blank slurries (containing the nutrient medium and vermiculite only) is named abiotic control. The vermiculite altered by the bacteria is labelled according their genetic name CHA0, CHA631, CHA77, CHA89, CHA400 and CHA661). All concentrations are averages of three measurements per glass pill.

\begin{tabular}{|c|c|c|c|c|c|c|c|c|}
\hline & Verm0 & Abiotic Control & CHA0 & CHA77 & CHA89 & CHA400 & CHA631 & CHA661 \\
\hline \hline Barium & $513 \pm 6.92$ & $469 \pm 4.62$ & $390 \pm 2.03$ & $304 \pm 2.9$ & $338 \pm 5.11$ & $385 \pm 6.14$ & $363 \pm 4.71$ & $409 \pm 8.55$ \\
\hline
\end{tabular}


which hydrolyze proteins), were studied. Various coldadapted proteases were formed by the bacteria Pseudoalteromonas issachenkonii as well as by the psychrophilic bacteria Pseudomonas strain $D Y$-A. These specific bacteria are living permanently in cold environments ranging from the deep sea to mountain and polar regions. The authors tested the effect of different divalent cations on protease activity. Among these cations $\mathrm{Ba}$ exhibited an influence on the relative activity of protease $\mathrm{E} 1$.

To complete the overall picture, in a short excursus, the role of bacteria and their remnants in the geological record will be depicted. Deep drilling into the marine floor has uncovered a vast sedimentary ecosystem of microbial cells (e.g. [75]). The same authors show that in subsurface sediments within a wide range of oceanographic settings, intact polar membrane lipids (biomarkers for the presence of live cells) were attributable to archaea and bacteria. The widespread occurrence of extended hopanoids (class of compounds, that have various functions in prokaryotes) in sediments illustrates the importance of bacterial lipid contributions to geological materials [76]. Terrestrial and marine bacteria and archaea (and their remnants after decay) can be useful as biomarkers in palaeoenvironmental investigations (e.g. [77-79]). It is pointed out that biomarkers can also be associated with planktonic bacteria [80]. Biomarker analyses of anoxic marine sediments showed bacterial fatty acids with strong ${ }^{13} \mathrm{C}$ depletion that are likely products of sulphate-reducing bacteria [81].

The literature about barium involved in metabolic processes of bacteria remains scarce. In summary, it can be concluded that barium can be incorporated within various metabolic products or be involved in metabolic activities of bacteria and archaea. Barium, in turn, can be released from these forms of life upon their decay. If metabolic use of $\mathrm{Ba}$ by different forms of life (including freshwater and marine bacteria) could be demonstrated, the findings could lead to exciting new discoveries and to further support barium's use as a palaeoproxy.

\section{CONFLICT OF INTEREST}

The author confirms that this article content has no conflict of interest.

\section{ACKNOWLEDGEMENTS}

I gratefully acknowledge the assistance of Geneviève Défago, Günter Kahr and Michael Plötze for the experiments. My appreciation is also expressed to Fabio Rezzonico and Michele Frapolli (Plant Pathology, ETH Zürich) for providing and cultivating the bacterium Pseudomonas fluorescens. Marcel Guillong's (Institute of Isotope Geochemistry and Mineral Resources at ETH Zürich) and Lydia Zehnder's (Institute for mineralogy and petrography at ETH Zürich) assistance with the LA-ICP-MS and the XRF respectively is also highly appreciated.

\section{REFERENCES}

[1] Goldberg ED, Arrhenius GOS. Chemistry of pelagic sediments. Geochim Cosmochim Acta 1958; 13: 153-212.
[2] Turekian KK, Tausch EH. Geochemistry of barium in marine sediments: Implications for its use as a paleoproxy. Geochim Cosmochim Acta 1964; 30: 696-7.

[3] Dehairs F, Chesselet R, Jedwab J. Discrete suspendes particles of barite and the barium cycle in the open ocean. Earth Planet Sci Lett 1980; 49: 528-50.

[4] Dymond J, Suess E, Lyle M. Barium in deep-sea sediment: A geochemical proxy for paleoproductivity. Paleoceanogr 1992; 7 : 163-81.

[5] Gingele FX, Dahmke A. Discrete barite particles and barium as tracers of paleoproductivity in South Atlantic sediments. Paleoceanogr 1994; 9: 151-68

[6] François R, Honjo S, Manganini SJ, Ravizza GE. Biogenic barium fluxes to the deep sea: implications for paleoproductivity reconstruction. Global Biogeochemi Cy 1995; 9: 289-303.

[7] Dymond J, Collier R. Particulate barium fluxes and their relationships to biological productivity. Deep-Sea Res II 1996; 43: 1281-308.

[8] Dehairs F, Shopova D, Ober S, Veth C, Goeyens L. Particulate barium stocks and oxygen consumption in the Southern Ocean mesopelagic water column during spring and early summer: relationship with export production. Deep-Sea Res II 1997; 44: 497-516.

[9] McManus J, Berelson WM, Klinkhammer GP, et al. Geochemistry of barium in marine sediments: Implications for its use as a paleoproxy. Geochim Cosmochim Acta 1998; 62: 3453-73.

[10] Klump J, Hebbeln D, Wefer G. The impact of sediment provenance on barium-based productivity estimates. Mar Geol 2000; 169: 25971.

[11] Van Beek P, Reyss JL, Bonte P, Schmidt S. Sr/Ba in barite: a proxy of barite preservation in marine sediments? Mar Geol 2003; 199 205-20.

[12] Weldeab S, Siebel W, Wehausen R, Emeis KC, Schmiedl G, Hemleben C. Late pleistocene sedimentation in the western mediterranean sea: Implications for productivity changes and climatic conditions in the catchment areas. Palaeogeogr, Palaeoclimatol, Palaeoecol 2003; 190: 121-37.

[13] Jacquet SHM, Dehairs F, Cardinal D, Navez J, Delille B. Barium distribution across the Southern Ocean frontal system in the Crozet-Kerguelen Basin. Mar Chem 2005; 95: 149-62.

[14] Dehairs F, Jacquet SHM, Savoye N, et al. Barium in twilight zone suspended matter as a potential proxy for particulate organic carbon remineralization: results for the North Pacific. Deep-Sea Res II 2008; 55: 1673-83.

[15] Paytan A, Kastner M. Benthic Ba fluxes in the central Equatorial Pacific, implications for the oceanic Ba cycle. Earth Planet Sci Lett 1996; 142: 439-50.

[16] Pfeifer K, Kasten S, Hensen C, Schulz HD. Reconstruction of primary productivity from the barium contents in surface sediments of the South Atlantic Ocean. Mar Geol 2001; 177: 13-24.

[17] Schmitz B. Barium, equatorial high productivity, and the northward wandering of the Indian continent. Paleoceanogr 1987; 2: 63-77.

[18] Murray RW, Leinen M. Chemical transport to the seafloor of the equatorial Pacific Ocean across a latitudinal transect at $135^{\circ} \mathrm{W}$ : Tracking sedimentary major, trace and rare earth element fluxes at the equator and the Intertropical Convergence Zone. Geochim Cosmochim Acta 1993; 57: 4141-63.

[19] Gingele FX, Zabel M, Kasten S, Bonn WJ, Nürnberg CC. Biogenic barium as a proxy for paleoproductivity: Methods and limitations of application. In: Riley G, Wefer G, Eds. Use of Proxies in Paleoceanography: Examples from the South Atlantic. Berlin, Heidelberg: Springer Verlag, 1999; pp. 345-64.

[20] Pirrung M, Illner P, Matthiessen J. Biogenic barium in surface sediments of the European Nordic Seas. Mar Geol 2008; 250: 89103.

[21] Bruland KW. Trace elements in sea-water. In: Riley JP, Chester R, Eds. Chemical Oceanography. London: Academic Press 1983; vol 8: pp. 57-220.

[22] Chan LH, Drummond D, Edmond JM, Grant B. Barium data from Atlantic GEOSECS expedition. Deep-Sea Res 1977; 24: 613-49.

[23] Broecker WS, Peng TH. Tracers in the sea. New York USA: Eldigio Press 1982.

[24] Jacquet SHM, Dehairs F, Rintoul S. A high resolution transect of dissolved barium in the Southern Ocean. Geophys Res Lett 2004; 31, L14301, doi: 10,1029/2004GL20016. 
[25] Bernstein RE, Byrne RH, Schijf J. Acantharians: a missing link in the oceanic biogeochemistry of barium. Deep-Sea Res I 1998; 45: 491-505.

[26] Prakash Babu C, Brumsack HJ, Schnetger B, Böttcher ME. Barium as a productivity proxy in continental margin sediments: a study from the eastern Arabian Sea. Mar Geol 2002; 184: 189-206.

[27] Chow TJ, Goldberg ED. On the marine geochemistry of barium. Geochim Cosmochim Acta 1960; 20: 192-98.

[28] Bishop JKB. The bariteopal-organic carbon association in oceanic particulate matter. Nature 1988; 332: 341-3.

[29] Bishop JKB. Regional extremes in particulate matter composition and flux: Effects on the chemistry of the ocean interior. In: Berger WH, Smetacek VS, Wefer G, Eds. Productivity of the ocean: present and past. Dahlem Workshop Reports, Life Science Research Report. New York: Wiley 1989; pp. 117-37.

[30] Falkner KK, Klinkhammer GP, Bowers TS, et al. The behavior of barium in anoxic marine waters. Geochim Cosmochim Acta 1993; 57: $537-54$.

[31] Turekian KK. Deep-sea deposition of barium, cobalt and silver. Geochim Cosmochim Acta 1968; 32: 603-12.

[32] Dehairs F, Goeyens L, Stroobants N, et al. On suspended barite and the oxygen minimum in the Southern Ocean. Global Biogeochem Cy 1990; 4: 85-102.

[33] Schulze FE, Thierfelder H. Bariumsulfat in Meerestieren (Xenophyophora, F.E. Sch.). Sitzungsberichte der Gesellschaft Naturforschender Freunde zu Berlin, 1905; 7-10.

[34] Tendal OS. A monograph of the Xenophyophoria (Rhizopodea, Protozoa). Galathea 2 Report 1972; 12: 7-99.

[35] Hubert G, Reider N, Schmitt G, Send W. Accumulation of barium in Müller's bodies of the Loxodidae (Ciliata, Holotricha). Zeitschrift für Naturforschung C 1975; 30: 422-3.

[36] Gayral P, Fresnel J. Exanthemachrysis gayraliae Lepailleur (Prymnesiophyceae, Pavlovales): Ultrastructure et discussion taxinomique. Protistologica 1979; 1: 271-82.

[37] Brook A, Fortheringham A, Bradley J, Jenkins A. Barium accumulation by desmids of the genus Closterium (Zygnemaphyceae). Briti Phycol J 1980; 15: 261-4.

[38] Finlay BJ, Hetherington NB, Davison W. Active biological participation in lacustrine barium chemistry. Geochim Cosmochim Acta 1983; 47: 1325-9.

[39] González-Muñoz MT, Fernández-Luque B, Martínez-Ruiz F, et al. Precipitation of barite by Myxococcus xanthus: Possible implications for the biogeochemical cycle of barium. Appl Environ Microbiol 2003; 69: 5722-5.

[40] Dehairs F, Lambert CE, Chesselet R, Risler N. The biological production of marine suspende barite and the barium cycle in the Western Mediterranean Sea. Biogeochem 1987; 4: 119-39.

[41] Stroobants NF, Dehairs F, Goeyens L, Vanderheijden N, Van Grieken R. Barite formation in the Southern Ocean Water column. Mar Chem 1991; 35: 411-21.

[42] Bernstein RE, Byrne RH, Betzer PR, Greco AM. Morphologies and transformations of celestite in seawater: the role of Acantharians in strontium and barium geochemistry. Geochim Cosmochim Acta 1992; 56: 3273-9.

[43] Bernstein RE, Byrne RH. Acantharians and marine barite. Mar Chem 2004; 68: 45-50.

[44] Arrhenius GOS. Pelagic sediments. In: Hill MN, Ed. The seas. New York: Interscience, 1963; vol 3: pp. 655-727.

[45] Bozatti EM, Schreiber B. Acantharia in the Atlantic Ocean, their abundances and preservation. Limnol Oceanogr 1971; 16: 677-84.

[46] Reider N, Ott HA, Pfundstein P, Schoch R. X-ray microanalysis of the mineral content of some protozoa. J Protozool 1982; 29: 15-8.

[47] Ku TL, Li YH, Mathieu GG, Wong HK. Radium in the IndianAntarctic Ocean south of Australia. J Geophys Res 1970; 75: 528692.

[48] Lea DW, Boyle E. Barium content of benthic foraminifera controlled by bottom-wate composition. Nature 1989; 338: 751-3.

[49] Lea DW. Constraints on the alkalinity and circulation of glacial circumpolar deep water from benthic foraminiferal barium. Global Biogeochem Cy 1993; 7: 695-710.

[50] Jeandel C, Dupré B, Lebaron G, Monnin C, Minster CF. Longitudinal distributions of dissolved barium, silica and alkalinity in the Western and Southern Indian Ocean. Deep-Sea Res I 1996; 43: 1-31.

[51] Stecher III HA, Kogut MB. Rapid barium removal in the Delaware estuary. Geochim Cosmochim Acta 1999; 63: 1003-12.
[52] Monnin C, Jeandel C, Cattaldo T, Dehairs F. The marine barite saturation state of the world's oceans. Mar Chem 1999; 65: 253-61.

[53] Renaudie J, Danelian T, Martin SS, Le Callonnec L, Tribovillard N. Siliceous phytoplankton response to a Middle Eocene warming event recorded in the tropical Atlantic (Demerara Rise, ODP Site 1260A). Palaeogeogr, Palaeoclimatol, Palaeoecol 2010; 286: 12134.

[54] Ganeshram RS, François R, Commeau J, Brown-Leger SL. An experimental investigation of barite formation in seawater. Geochim Cosmochim Acta 2003; 67: 2599-605.

[55] Sternberg E, Degui T, Tung-Yuan H, Jeandel C, Morel FM. Barium uptake and adsorption in diatoms. Geochim Cosmochim Acta 2005; 69: 2745-52.

[56] Müller B. Impact of the bacterium Pseudomonas fluorescens and its genetic derivatives on vermiculite: Effects on trace metals contents and clay mineralogical properties. Geoderma 2009; 153: 94-103.

[57] Beveridge TJ, Fyfe WS. Metal fixation by bacterial cell walls. Can J Earth Sci 1985; 22: 1893-8.

[58] Brantley SL, Liermann L, Bau M, Wu S. Uptake of trace metals and rare earth elements from Hornblende by a soil bacterium. Geomicrobiol J 2001; 18: 37-61.

[59] Duffy BK, Défago G. Zinc improves biocontrol of fusarium crown and root rot of tomato by Pseudomonas fluorescens and represses the production of pathogen metabolites inhibitory to bacterial antibiotic biosynthesis. J Phytopathol 1997; 87: 1250-7.

[60] Duffy BK, Défago G. Trace mineral amendments in agriculture for optimizing the biocontrol activity of plant-associated bacteria. Effect of Mineral-Organic-Microorganism Interactions on Soil and Freshwater Environments. Proceedings of an International Symposium on the Effect of Mineral-Organic-Microorganism Interactions on Soil and Freshwater Environments, $2^{\text {nd }}$, Nancy, France 1999; pp. 295-304.

[61] Günther D, Frischknecht R, Heinrich CA, Kahlert HJ. Capabilities of an argon fluoride $193 \mathrm{~nm}$ excimer laser for laser ablation inductively coupled plasma mass spectrometry microanalysis of geological materials. J Anal At Spectrom 1997; 12: 939-44.

[62] Longerich HP, Jackson SE, Günther D. Laser ablation inductively coupled plasma mass spectrometric transient signal data acquisition and analyte concentration calculation. J Anal At Spectrom 1996; 11: 899-904.

[63] Heinrich CA, Pettke T, Halter WE, et al. Quantitative multielement analysis of minerals, fluid and melt inclusions by laserablation inductively-coupled mass-spectrometry. Geochim Cosmochim Acta 2003; 67: 3473-97.

[64] Müller B, Défago G. Interaction between the bacterium Pseudomonas fluorescens strain CHA0 and vermiculite: Effects on chemical, mineralogical and mechanical properties of vermiculite. J Geophys Res 2006; 111, G02017: doi:10.1029/2005JG000054.

[65] Müller B, Guillong M. Laser Ablation ICP-MS analyses of marine sediments from the Oxfordian (Late Jurassic): A comparison of three preparation techniques. The Open Mineralogy Journal 2010; 4: 9-19, DOI: $10.2174 / 1874456701004010009$.

[66] Müller B. Trace elements in marine sediments from the Oxfordian (Late Jurassic): Implications for seawater chemistry, erosional processes, changes in oceanic circulation and more. The Open Geology Journal 2012; 6: 32-64, DOI: $10.2174 / 1874262901206010032$.

[67] Mason B, Moore CB. Principles of geochemistry. New York: Wiley; 1982

[68] Caccavo F. Protein-Mediated adhesion of the dissimilatory Fe(III)reducing bacterium Shewanella alga $\mathrm{BrY}$ to hydrous ferric oxide. Appl Environ Microbiol 1999; 65: 5017-22.

[69] Goytain A, Quamme GA. Functional characterization of ACDP2 (ancient conserved domain protein), a divalent metal transporter. Physiol Genomics 2005; 22: 382-9.

[70] Vahrenkamp H. Metalle in Lebensprozessen. Chemie unserer Zeit 1973; 7: 97-105.

[71] Wang CY, Yang P, Shi JD, et al. Molecular cloning and characterization of the mouse $A c d p$ gene family. Genomics 2004; 5: 7-16.

[72] Selenska-Pobell S, Panak P, Miteva V, Boudakov Y, Bernhard G, Nitsche H. Selective accumulation of heavy metals by three indigenous Bacillus strains, B. cereus, B. megaterium and $B$. sphaericus, from drain waters of a uranium waste pile. FEMS Microbiol Ecol 1999; 29: 59-67. 
[73] Dong D, Li Y, Zhang J, Hua X. Comparison of the adsorption of lead, cadmium, copper, zinc and barium to freshwater surface coatings. Chemosphere 2003; 51:369-73.

[74] Xiong H, Song L, Xu Y, Tsoi MY, Dobretsov S, Qian PY. Characterization of proteolytic bacteria from the Aleutian deep-sea and their proteases. J Ind Microbiol Biot 2007; 34: 63-71.

[75] Lipp JS, Morono Y, Inagaki F, Hinrichs KU. Significant contribution of Archaea to extant biomass in marine subsurface sediments. Nature 2008; 454: 991-4.

[76] Brassel SC, Wardroper AMK, Thomson ID, Maxwell JR, Eglinton G. Specific acyclic isoprenoids as biological markers of methanogenic bacteria in marine sediments. Nature 1981; 290: 693-6.

[77] Pancost RD, Boot CS. The palaeoclimatic utility of terrestrial biomarkers in marine sediments. Mar Chem 2004; 92: 239-61.
[78] Ventura GT, Kenig F, Reddy CM, et al. Molecular evidence of Late Archan archaea and the presence of a subsurface hydrothermal biosphere. Proc Natl Acad Sci USA 2007; 104: 14260-5.

[79] Rossel PE, Lipp JS, Fredricks HF, et al. Intact polar lipids of anaerobic methanotrophic archaea and associated bacteria. Organic Geochemistry 2008; 39: 992-9.

[80] Brocks JJ, Schaeffer P. Okenane, a biomaker for purple sulfur bacteria (Chormatiaceae), and other new carotenoid derivatives from the 1640 Ma Barney Creek Formation. Geochim Cosmochim Acta 2008; 72: 1396-414.

[81] Orphan VJ, Hinrichs KU, Ussler III W, et al. Comparative Analysis of Methane-Oxidizing Archaea and Sulfate-Reducing Bacteria in Anoxic Marine Sediments. Appl Environ Microbiol 2001; 67: 1922-34.

(C) Barbara Müller; Licensee Bentham Open.

This is an open access article licensed under the terms of the Creative Commons Attribution Non-Commercial License (http://creativecommons.org/licenses/by$\mathrm{nc} / 3.0 /$ ) which permits unrestricted, non-commercial use, distribution and reproduction in any medium, provided the work is properly cited. 